\title{
Afyonkarahisar ilindeki Altı Okulda Bulunan 1930-1940 ve 2000-2010 Yıllarına Ait Teftiş Raporlarına Göre İlköğretimde Öğrenci Sorunları ve Çözüm Önerileri*
}

\author{
Muzaffer ŞiMŞEK'
}

\begin{abstract}
Öz: Bu araştırmada, Afyonkarahisar ili ilköğretim okullarının 1930-1940 ve 2000-2010 yıllarına ait teftiş raporlarına göre Türkiye Cumhuriyetinin kuruluş yılları ile 2000- 2010 yılları arasında okul denetimlerine yansıyan bulguların karşılaştırılarak her iki dönem arasındaki öğrenci sorunlarında benzerlik ve farklılıkların saptanması amacıyla yapılmıştır. Araştırma ilköğretim müfettişlerinin rehberlik ve teftiş sonrası yazdıkları raporlara dayanmaktadır. Bu teftiş raporları, ilköğretimin sorunlarını ve dönemlerdeki öğrenci durumlarını belirlemeye yöneliktir. Araştırma, bir durum çalışması olarak tasarlanmıştır. Veriler, altı okuldan elde edilen teftiş raporlarının doküman analizine tabi tutulması ile elde edilmiştir. Araştırma sonuçlarına göre, 2000-2010 döneminde sistemin, ders programları ve belirlenen eğitim hedefleri açısından öğrencilerden yaşları üzerinde beklentisinin olduğu görülmektedir. İlköğretim çağındaki çocuklara yönelik olarak 1930-1940 döneminde özen gösterilen vatandaşlık bilgisi yerine 2000-2010 yılları arasında daha fazla akademik bilgi yüklendiği sezilmektedir. Öte yandan, disiplin olaylarında yıllar ilerledikçe öğrencilere yönelik olarak daha ağır cezaların mevzuatta yer aldığı sonucuna ulaşılmıştır.
\end{abstract}

Anahtar Sözcükler: Teftiş, Teftiş raporları, İlköğretimde denetim, Öğrenci sorunları, Öğrenci disiplini

\section{Student Problems in Elementary Schools and Possible Solutions for those Problems in Inspection Reports to be issued between 1930 - 1940 and 2000-2010 in Six Schools in} Afyonkarahisar Province

\begin{abstract}
This present paper aims to compare the findings of the inspectorate audit reports to be carried out in Afyonkarahisar Province during the founding years of the Republic from 1930 to 1940 and then 2000 to 2010 in terms of similarities and differences of problems of elementary school students and possible solutions to those problems as stated in the inspectors' reports. This research was based on the reports of the inspectors who had carried out supervisory and inspectorate duties in the elementary schools. These reports were largely on the problems of elementary school students and about the ways to solve these identified problems. This survey was designed as a case study. The data was collected through the document analysis of inspectorate reports available in six schools. According to the results of the survey, the reports indicate a high degree of expectations from the students regarding the curricular content and behavioural objectives beyond the students' age-specific potentials in the years from 2000 to 2010. The citizenship education which was particularly emphasized during the 1930-1940 period was replaced with a heavy load of academic knowledge. On the other hand, reports indicate a trend towards the placement of heavier disciplinary measures in the legislations against the students.
\end{abstract}

Keywords: Inspection, Inspectorate reports, Inspection (and supervision) in primary education, Student problems, Student discipline

* Bu çalışma, Ankara Üniversitesi Eğitim Bilimleri Enstitüsünde, Prof. Dr. İnayet AYDIN'ın danışmanlığında yapılan doktora tezinden üretilmiştir.

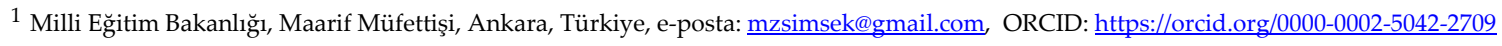


Televizyon, internet veya yazılı basın aracıllı̆g 1 ile evlerimize, iş yerlerimize giren dünyanın farklı yerlerindeki olaylar küresel ve yerel anlamda değişimi hızlandırmakta, olumlu veya olumsuz yönde toplumları değişime zorlamaktadır. Eğitim sistemleri de bu zorlamalardan etkilenmekte, eğitmek zorunda olduğu yeni kuşakları yeni durumlara uyarlamak için modern eğitim programları geliştirmeye çalışmaktadır.

İçinde bulunduğumuz küreselleşme ortamında ortaya çıkan yeni paradigmalar doğrultusunda bir yandan eğitim sistemleri, kendini değiştirmeye ve dönüştürmeye çalışırken, diğer yandan hizmet ettiği genç kitlenin akıl ve bilimin ışığında, laik, modern yaşam biçimimi, aletli modern üretim biçimleri gibi hızla değişen değerler sistemine ayak uydurabilme için okullar da kendini değiştirme çabası içindedir. Benzer bir değişim ve dönüşüm serüveni Cumhuriyet okulları ve Cumhuriyet eğitim sistemi için de geçerlidir. Cumhuriyet eğitim sistemine farklı zamanlarında farklı paradigmalar hakim olmuş, bu farklı paradigmalar eğitim sistemimizde farklı yönelim ve uygulamalara yol vermiştir. Cumhuriyet dönemi eğitim sistemimizin kuruluşu, gelişmesi, olgunlaşması süreçlerini bilmemiz bulunduğumuz noktaya nasıl geldiğimizi ve bugüne hakim olan uygulamaları anlamamızı daha iyi açıklayacaktır.

Öncelikle bilimdeki değişim, dönüşüm ve yeni oluşumları eğitim sistemine aktarmakta geç kalınmaması, sorunların zamanında tespit edilmesi ve denetimin niteliği ve öğretmene yararı konusunda duyarlı olunması gerekmektedir. Gelişen ve değişen bu ortamda, sistemlerin dengeleri bozulmakta, yeni durumlara uyum sağlayabilmek için denetim alt sistemlerinin işlevlerine her zamankinden çok gereksinim duyulmaktadır (Taymaz, 2005).

Bu nedenle ülkenin içinde bulunduğu genel durumu da kısaca incelemekte yarar vardır. Çünkü bulunulan durumda, ülkenin şartlarını göz ardı ederek sadece konuyu ilköğretim (eğitim, maarif) müfettişlerinin çalışmalarına dayandırmak çok da tutarlı olmayan bir yaklaşım olacaktır. Var olan durumu saptarken, eğitimi etkileyen sosyal, ekonomik, siyasal faktörlerin bilinmesinde yarar vardır.

\section{Cumhuriyete Giden Yol ve Kuruluş}

Birinci Dünya Savaşı'ndan yenik çıkarak 30 Ekim 1918 tarihinde Mondros Mütarekesini imzalamak zorunda kalan Osmanlı İmparatorluğu, fiilen yok olma aşamasına gelmişti. Anadolu'nun birçok yeri işgal edilmeye başlanmıştı. Ülke, 15 Mayıs 1919 tarihinde İzmir'in Yunanlılar tarafından işgal edilmesi ile başlayan işgal yılları ardından milli mücadele yıllarına tanık olmuştur (Feyzoğlu, 1982).

24 Temmuz 1923 tarihinde imzalanan Lozan Antlaşması ile yeni Türkiye Cumhuriyeti, Osmanlı borçlarının \%62'sini ödemeyi kabullenmek zorunda kalmış, 1929 yılından başlayarak 15 yıl boyunca bütçesinin \%12-18'ini Osmanlı borçlarının geri ödenmesine ayırmıştır. Ayrıca kapitülasyonlarla verilen işletmelerin tekrar millileştirilmesi de ayrı bir oran tutmaktadır. Bu zor şartlara rağmen genel bütçenin milli savunma ve iç işlerinden sonra en büyük payını Millî Eğitim Bakanlığı almaktadır. Bu süreçte halkın okumaya karşı duyduğu ilgi büyüktü, evlerin kerestelerini sökerek okullarını yapan köyler görülmektedir (Başöz, 1995; Ergün, 1997). Buna rağmen, yerleşim yerlerinin durumu, nüfusun yapısı, öğretmen ve okul sayıları eğitimden beklenen sonucun en önemli engellerini oluşturmaktadır (Kodamanoğlu, 1964).

1927 sayımına göre ülkenin nüfusu 13.648.270'tir. Bunun \%75'ten fazlası köylerde yaşamaktadır. 1935 istatistiklerine göre Türkiye'de 34.876 köy ve bucak vardır. Nüfusu 501'den çok olan köy sayısı 6,866, 401-500 arası olan köy sayısı 3,298, 201-400 arası olan köy sayısı 14,743, 200'den az olan köy sayısı 12,074'tür. Nüfusu 400'den az olan 26.817 köye okulu ve eğitimi sokabilmek için ne özel idarelerin ne de hükümetin bütçesi yeterliydi. Var olan 5,401 köy okulu ise nüfusu 400'den fazla olan köylerdedir (Başgöz, 1995). Türkiye'deki okul, öğrenci ve öğretmen sayıları MEB'nın 2000-2011 istatistiklerine göre Tablo 1'de gösterilmiştir.

Tablo 1'de yer alan sayısal verilerle değerlendirme yapıldığında 1923 yılında başlayan, 1928 yılındaki Harf Devrimi ile hız kazanan ve ulusal eğitimi hedefleyen çalışmaların 1923-1924 döneminden 1940-1941 dönemine kadar öğrenci, öğretmen ve okul sayıları açısından \%100 artışa ulaştığı, 1940 yılında Köy Enstitülerinin de devreye girmesi ile bu oranların çok yukarı taşındığı görülmektedir. Buna bağlı olarak da 1926-1927 yılında ilkokulda \%39 olan okullaşma oranı 1944-1945 yılında \%52, 1961-1962 yılında \%79, 1996- 1997 yılında \%89,40, 1999-2000 yılında \%93,54, 2009-2010 yılında \%98,47 oranına çıkarak evrensel okuma- yazma oranı olan \%100 
hedefine yaklaşmıştır (MEB, 2015).

Diğer yandan ülkenin sosyal ve ekonomik gerçeklerine uyacak bir eğitim sistemi kurma çalışmaları da sürdürülmektedir. Gerek yurt içinden gerek yurt dışından getirilen uzmanlarca yapılan inceleme ve raporlarına rağmen ülkenin eğitim sorununu acilen çözecek bir proje tam olarak oturtulamamıştır. Bu çalışmalar program boyutunda da sürdürülmüş, 1924, 1926, 1931, 1936, 1948, 1968 yıllarında yeni programlar geliştirilmiştir.

Tablo 1. Resmi Okul Sayıları

\begin{tabular}{ccccc}
\hline Yıl & Öğrenci Sayısı & Öğretmen Sayısı & Okul Sayısı & Ülke Nüfusu \\
$1923-1924$ & 341.941 & 10.238 & 4.894 & $13.648 .270(1927)$ \\
$1930-1931$ & 489.299 & 16.318 & 6.598 & $16.158 .018(1935)$ \\
$1940-1941$ & 955.747 & 20.564 & 10.596 & 17.820 .950 \\
$1950-1951$ & 1.616 .626 & 35.871 & 17.428 & 20.947 .188 \\
$1960-1961$ & 2.866 .501 & 62.526 & 24.398 & 27.754 .820 \\
$1970-1971$ & 5.013 .408 & 132.721 & 38.234 & 35.605 .176 \\
$1980-1981$ & 5.653 .069 & 211.573 & 45.507 & 44.736 .957 \\
$1990-1991$ & 6.870 .638 & 234.154 & 50.669 & 56.473 .035 \\
$2000-2001$ & 10.289 .233 & 345.001 & 36.047 & 67.803 .927 \\
$2009-2010$ & 10.257 .169 & 453.311 & 32.146 & 73.722 .988 \\
$2014-2015$ & $5434150+5278=$ & $295252+296065$ & $27544+16969$ & $77.695 .904(2014)$ \\
& $=10710712257$ & $=591317$ & $=44513$ &
\end{tabular}

Kaynak: MEB (2015), (www.meb.gov.tr), Milli Ĕgitim İstatistikleri MEB, 2000-2015, (www.meb.gov.tr/mevzuat); (Okul sayısındaki azalma kapanan köy okullarına bağlıdır İlköğretime geçmeden önceki dönem sadece ilkokul sayılarını kapsar. 2014-2015 ilkokul+ ortaokul şeklindedir.)

\section{3-1940 Dönemi Eğitim Girişimleri}

1936 yılı İlkokul Programının giriş bölümünde sözü edilen ve Cumhuriyet Halk Partisinin ulusal eğitim programını yansıtan bölümde Atatürk Türk devrimi, cumhuriyet, ulus, halk, millet, bağımsızlık, milli birlik, ortak mal (kültür ve kıymetler), yeni kültür, muasır medeniyetler, herkesin eğitimi gibi kavramlara çok yer vermiştir. Sonuç olarak hedefin, programın 2. maddesinde açıklanan "Kuvvetli Cumhuriyetçi, ulusçu, halkçı, devletçi, laik ve devrimci yurttaş yetiştirmek" olarak vurgulandığı ve bu hedefe ulaşmak için gerekli hazırlıkların yapıldığı görülmektedir. Ülke gerçeklerinin olduğu gibi sorun kabul edilerek çözüm arandığı, sadece program çalışması ile yetinilmeyerek programın kime, nerede, nasıl, kiminle ve ne amaçla uygulanacağının ayrıntılı olarak düşünüldüğü ve zaman içerisinde uygulamaya konulduğu görülmektedir. Ülkenin geldiği nokta düşünüldüğünde çıkış noktasının doğru seçildiği söylenebilir.

Özel (2007), Atatürk Dönemi çalışmalarındaki temel eğitim politikasında öğrenci, öğretmen, ders programları, okul konularının her birine ayrı önem verildiğini vurgulamaktadır. Ülke içinde eğitim gören insan sayısını artırmak, kaliteli ve yeterli sayıda öğretmen yetiştirmek, ders programlarını günün şartlarına ve devletin dayandığı temel niteliklere uygun hale getirmek, okulların çeşitli sıkıntılarına son vermek yönünde çalışmalar yapıldığını belirtmektedir.

Dönemin mevzuatına da giren eğitimin hedefleri İlkmektepler Talimatnamesi'nde kısaca "Uygun çevre, bedence ve ruhça sağlıklı nesiller yetiştirmek, lüzumlu bilgi, milli cemiyet, Türk Cumhuriyeti, milli hayat, milli iktisat, Türklük, Türk vatanı, milli hisler, Türk inkılabı, vatan, milliyet sembolü bayrak, bayrak merasimi" kelimeleri ile özetlenebilir. Bütün bu vurgular, dönemin yeni toplum yaratma çalışmasında eğitimin üstlendiği görev ve görevin başlangıç noktasının seçimi de sistemin kısa sürede yaygınlaşmasına yardımcı olmuştur. Söyleneni anlayabilecek bir toplum yaratılması için eğitim sistemine el atılmış, eğitimin önceliğinin nüfusun çoğunluğunu oluşturan köylüye verilmesi amaçlanmıştır.

Atatürk'ün gösterdiği hedeflere ulaşmayı amaçlayan ve öğretmenlere yön verecek, eğitimi belirli bir sistematik içerisine sokarak örgütleyecek bir eğitim örgütün eksikliğini gidermek için 1920 yılında Maarif Vekili Rıza Nur Bey göreve getirilmiştir. Başlayan arayışlar ve çalı̧malar Hamdullah Suphi Bey, Mehmet 
Vehbi Bey, İsmail Safa Bey, Vasıf Bey, Mustafa Necati Bey dönemine kadar sürmüş ve Bakanlık teşkilatı belirli bir düzeye getirilmiştir. Cumhuriyetin kurulmasından önce ve daha sonrasında; özellikle Atatürk tarafından eğitime verilen önem; göreve yukarıda isimleri sayılan bakanların çabaları ve özellikle 22 Kasım 1924 ile 1 Ocak 1929 tarihleri arasında görev yapan Bakan Mustafa Necati döneminde büyük bir örgütlenme gerçekleştirilmiştir.

1 Kasım 1928 tarihinde Latin harflerinin kabul edilmesi ile Türkçenin yerleşmeye başlaması; günümüz eğitim sisteminin temellendirildiği yıllar olmuştur. Köylere okul yapımı ve yapılacak bu okullara öğretmen yetiştirmenin yanında ders programlarının yenilenmesi de temel amaç olmuştur (Altunya, 2009; Başgöz, 1995; Binbaşığlu, 2005). 22 Mart 1926 tarih ve 789 sayılı Maarif Teşkilatına Dair Kanun'a dayanarak okul sistemi yeniden düzenlenmiş, kentlerde 5 yıllık, köylerde 3 yıllık ilkokullar açılması kararlaştırılmıştır. Bakan Mustafa Necati Bey, 20 Mart 1926 günü Bakanlık Teşkilat Yasa Tasarısı görüşmelerinde 3 yıllık köy okullarının açılmasına karşı yapılan eleştirilere verdiği cevapta şöyle demektedir (TBMM, 20/03/1926 günü oturum tutanakları, Akt. İnan, 1980):

\begin{abstract}
... Halis Bey, köy çocukları sorununu söz konusu ettiler. Gerçekten köy çocuklarına ayrı bir öğrenim vermek gerekir. Bunların babaları çocuksuz yaşayamıyorlar. Çocuğu çiftinde, tarlasında çalıştırmaya ve ineği sağdırmaya zorunludur. Onun içindir ki köy okullarında öğrenim süresini üç yıl yaptık. Bu üç yıl içinde çocuklar kentte oldukları gibi okuyamayacaklardır.

Kimi kez günde 2-3 saat okuyacaktır. Okulları kimi kez altı ay tatile girecek ve çocuklar babalarının evlerinde kalacaklardır. Gereksinimlere göre onlara eğitim vereceğiz, amacımız budur.40 kelimden fazla olan doğrudan alıntı yazımı bu şekilde olmalıdır.
\end{abstract}

Yine aynı görüşmelerde köy yatılı okulları ve köy okulları ile ilgili konuşmasında Bakan Mustafa Necati Bey şöyle demektedir (TBMM, 20/03/1926 günü oturum tutanakları, Aktaran: İnan, 1980):

\begin{abstract}
Besim Atalay Bey arkadaşımız da köy yatılı okulları doğru değildir buyurdular. Eğer köylerin sayısı belli olsaydı ve her köy 300 evli bulunsaydı ve öğretmen sayısı da daha çok olsaydı, buraya hiç böyle bir kayıt koymaya gerek kalmazdı.

Ne var ki, bugün köylerin sayısı 42.000'i geçtikten ve ev sayıları belirsiz olduktan sonra bir yatı okulu yapmanın ve her köyün çocuklarını toplayıp orada okutmanın çok iyi olduğu saptanmıştır. Yalnız bir noktayı sunayım: Köy çocuklarını köyden alıp da kentte okutmak yanlıştır.

Bu dizge uygulanmış, sakıncaları görülmüştür. Köyden çocukları almışlar, kent okulunda okutmuşlar. Okulu bitirince o çocuklar köyüne dönmek istememişlerdir. Elimizde böyle çocuklar vardır. Onun için köy çocuklarını kentte okutmayacağız, köyünde okutacağız. O, köyünde ne görüyorsa, o yaşamı yaşayacaktır. Şu demek, okulun içinde büyük bir bahçe (arsa) olacak orada alışacaklar, hayvan bakmasını öğrenecek, böylelikle köylerinden ayrılmayacaklar. Doğal olarak bunların izlencelerini Öğretim ve Eğitim Kurulu izleyecek, yapacaktır. Köy öğretmenlerini getireceğiz, onların kişisel düşüncelerini de dikkate alacağız. Ona göre okul açacağız, ona göre de izlence yapacağız.
\end{abstract}

Okulların süresi ile ilgili yapılan eleştirilere ise Mustafa Necati “Demin de saygıyla belirttiğim gibi bu, bilim kurulu ile ilgili bir konudur. Beş yıl derlerse, beş yıl olacaktır. Koyduğumuz süre en az bir süredir" (İnan, 1980, 81) diyerek köy okullarının üç yıl süreli ve bölgenin iklim ve coğrafi yapısına uygun program geliştirilerek uygulanacağını ifade etmektedir.

Yeni alfabenin kabulü ile başlayan köye eğitim politikası ile ilgili olarak dönemin Başbakanı İsmet İnönü, 08/11/1928 günü, Türkiye Büyük Millet Meclisinde yaptığ 1 konuşmada, hükümetinin hedeflerini şöyle açıklamıştır (TBMM, 8 Kasım 1928, 3.Dönem, 2. Yasama Yılı, 5. Cilt, 3. Birleşim, s. 26-29, Aktaran Öztürk, 1968):

Türk harflerinin bütün vatandaşlara kapılarının önünde ve işlerinin başında öğretilebilmesi için daha bu sene içinde millet mektepleri teşkilatı yapacağız.

$\mathrm{Bu}$ teşkilat şehir ve köy, bütün yurdu kaplayacak, vatandaşların işlerinin maişetlerinin en müsait devirlerinde ve yanlarında ya iki aylık ya dört aylık kurslar açılacak, şehirde ve köyde mekteplere, muayyen içtima mahallerine gelmeğe vakitleri müsait olmayan vatandaşlar için seyyar muallim teşkilatı yapılacak; devletin en büyüğünden en küçüğüne kadar bütün memurları millet mektepleri teşkilatında ihtiyaca göre çalışacaklar.

Reisicumhur Hazretleri millet mektepleri teşkilatının umumi reisliğini ve baş muallimliğini kabul buyurmuşlardır. Bu teşkilat ile bir senede, vatandaşın maişet hayatındaki düzeni hiç sarsmaksızın geçkin yaşlarda bir kaç yüz bin nüfusu okutabileceğimizi hesap ediyoruz.

İlk tahsili fiilen umumi bir hale getirmek meselesini enine boyuna ve çok özen ile tetkik ettik. Bugünkü usul ile ilk tahsil varabileceği hedeflere varmış gibidir. İdarei hususiyelerin yerli varidat ile yerli ilk mekteplerle uğraşması tarzında şimdiye kadar takip edilen usulün bugünkü vaziyeti şudur. Varidatı müsait olan yerler ilk ihtiyaç haricinde geniş sarfiyata temayül edecek hale gelmişler, varidatı müsait olmayan yerler tevakkuf ihtimali karşısında kalmışlardır. Halbuki bu memleketin ilk tahsile umumi ve hususi idarelerden tahsis ettiği varidat ki 20 milyonu geçecek kadardır. Bir 
elden yani Büyük Millet Meclisinin Maarif Vekaletinden sarf olunarak bütün memlekette bir plana göre mütevazi fakat sıhhi, temiz ihtiyaca kâfi binalarla ilk tahsili bütün vatana fiilen umumi kılmak mümkün olacaktır. Tetkikatımız seneler sürdü. Vasıl olduğumuz kanaat budur.

Ders programlarının hazırlı̆̆ı, ilköğretim, ortaöğretim ve yükseköğretim sistemleri ile ilgili alt yapı ve mevzuat oluşturulmuştur (Ergün, 1997). Alt yapı ile ilgili bu hazırlıklardan sonra geliştirilen programlarda da sistemin hedefleri ortaya konmaya başlamıştır. Önceliğin tabanın eğitimi olarak ortaya çıktığı bu dönemde, yönetimle halk arasındaki bağı kuracak olan dilin en kısa sürede yerleştirilmesi olarak öne çıkmaktadır. Bu nedenle köye uygun öğretmen ve program çalışmaları hız kazanmış, köy eğitmenleri denemesinin başarılı olması ile Köy Enstitülerinin kurulmasına başlanmış, ek kuvvet olarak Halk Mektepleri devreye sokulmuş, ilerleyen yıllarda Halk Evleri aracılığı ile toplumun ortak kültürü yaratılmaya çalışılmıştır.

Bu esaslara göre 1936 İlkokul Programı ile oluşturulması düşünülen ulusal eğitimin hedefleri ana başlıklar halinde şu şekilde sıralanmaktadır (Edis, 1947):

A) Eğitim siyasamızda temeltaşı bilimsizliği gidermektir. Kültür işinde, her gün daha çok çocuk ve yurtdaş okuyup yetiştirecek bir program güdülecektir. Bu düsturun ifade ettiği gayeyi tahakkuk ettirmek için ilkokul öğretmeni kendine düşen ödevi yapmalı, bulunduğu yerde okumamış, yetişmemiş yurtdaş bırakmamağı iş edinmelidir.... Hasılı okul öğretmeni, okulu, bulunduğu yerin eğitim ihtiyacını temin edecek esaslı ve verimli bir ocak haline getirmek için elinden ne gelirse yapmalıdır. Cumhuriyetin kendisine verdiği ödevi yerine getirmiş olmıyacağını bilerek ona göre canla başla çalışmalıdır.

B) Kuvvetli Cumhuriyetçi, ulusçu, halkçı, devletçi, laik ve devrimci yurtdaş yetiştirmek bütün öğretim derecelerinde yüküm ve özen noktasıdır. «Türk ulusunu, kamutayı ve Türk Devletini sayın tutmak ve tutturmak, bütün yurtdaşlara bir ödev olarak aşılanacaktır.» Bunun için ilkokulda bütün derslerin, eğitim sisteminin ve okul hayatının bu düsturda yazılı esasları tahakkuk ettirecek bir yolda ilerlemesi şarttır.

C) Fikri olduğu gibi bedeni gelişmişliğe de önem vermek ve hele irayı (karakter) ulusal derin tarihimizin gösterdiği yüksek derecelere çıkarmak büyük gayedir. Eğitim ve öğretimde güdülen usul, bilgiyi, yurtdaşa maddi hayatta başarı elde ettiren bir cihaz haline getirmektir.

D) Eğitim her türlü urasadan (etki), yad ve yabancı fikirlerden uzak, üstün, ulusal ve yurtçu olmalıdır.

E) Talebenin girişim kapasitesini kırmadan, onun hayatta kusurlu olmaktan korumak için ciddi biryasav ve düzene, içten bir ahlak anlayışına alıştırmak,

F) Tarihini iyi bilmesi,

G) Türk dilinin ulusal, tükel (tam, bütün) bir dil haline gelmesi"

Hedeflerin belirlenmesi dışında aynı programda öğretmenlerden beklentiler de açıklanmaktadır. Bu açıklamada "Kültür Bakanlığı, bütün öğretmenlerimizin Atatürk'e, Atatürk devrimine, Türk milletine ve Cumhuriyet rejimine bağlılı̆̆ına, yurtseverliklerine, mesleğe karşı olan derin ilgilerine emin olarak ulusal eğitim ve öğretim işinin en canlı yapıcısı ve başarıcısı olmalarını kendilerinden bekler" denilmektedir.

\section{0-2010 Dönemi Eğitim Girişimleri}

Cumhuriyetin ilk dönemi ile ilgili var olan durumun tespitinden sonra araştırmanın yapılmasına başlanılan 2010 yılı ve öncesindeki 10 yıl karşılaştırma yılı olarak alınmıştır. Bu nedenle çalışma, Osmanlıca yazılı belgelerin kaldırıldığı 1930 yılı başlatılarak sonraki 10 yıl ile sınırlandırılmış, araştırmanın yapılmasına başlanan 2010 yılı ile geriye doğru son 10 yıl olan 2000 yılı ile sınırlı tutulmuştur. Bu kapsamda araştırmanın 2000-2010 yılları arasına denk gelen son yıllarındaki gelişmelere de kısaca bakmakta yarar vardır.

2000 - 2010 döneminde, raporlara yansımayan, ancak dönemin eğitim politikalarını belirleyen hükümet programlarının incelenmesi yoluyla 2000-2010 dönemi eğitim politikaları tespit edilmeye çalışılmıştır. Dönemin eğitim hedeflerini gerçekleştirecek olan Millî Eğitim Bakanlığının teşkilat yasası olan 24/6/1973 tarihli Resmi Gazete'de yayımlanan 1739 sayılı Millî Eğitim Temel Kanunu'nun genel amaçlarını belirleyen 2.maddesinde Türk Milli Eğitiminin genel amacı şöyle tanımlanmıştır:

Türk Milletinin bütün fertlerini,

1. (Değişik: 16/6/1983 - 2842/1 md.) Atatürk inkılap ve ilkelerine ve Anayasada ifadesini bulan Atatürk milliyetçiliğine bağll; Türk Milletinin milli, ahlaki, insani, manevi ve kültürel değerlerini benimseyen, koruyan ve geliştiren; ailesini, vatanını, milletini seven ve daima yüceltmeye çalışan, insan haklarına ve Anayasanın başlangıcındaki temel ilkelere dayanan demokratik, laik ve sosyal bir hukuk Devleti olan Türkiye Cumhuriyetine karşı görev ve sorumluluklarını bilen ve bunları davranış haline getirmiş yurttaşlar olarak yetiştirmek;

2. Beden, zihin, ahlak, ruh ve duygu bakımlarından dengeli ve sağlıklı şekilde gelişmiş bir kişiliğe ve karaktere, hür ve bilimsel düşünme gücüne, geniş bir dünya görüşüne sahip, insan haklarına saygıllı, kişilik ve teşebbüse değer veren, 
topluma karşı sorumluluk duyan; yapıcı, yaratıcı ve verimli kişiler olarak yetiştirmek;

3. İlgi, istidat ve kabiliyetlerini geliştirerek gerekli bilgi, beceri, davranışlar ve birlikte iş görme alışkanlığı kazandırmak suretiyle hayata hazırlamak ve onların, kendilerini mutlu kılacak ve toplumun mutluluğuna katkıda bulunacak bir meslek sahibi olmalarını sağlamak;

Böylece, Millî Eğitim Temel Kanunu’ na göre eğitimin amacl, bir yandan Türk vatandaşlarının ve Türk toplumunun refah ve mutluluğunu artırmak; öte yandan milli birlik ve bütünlük içinde iktisadi, sosyal ve kültürel kalkınmayı desteklemek ve hızlandırmak ve nihayet Türk Milletini çağdaş uygarlığın yapıcı, yaratıcı, seçkin bir ortağı yapmaktır" diye açıklanmakta, aynı yasada yer alan 23. madde de yer alan İlköğretimin amaç ve görevleri de:

\footnotetext{
"Illköğretimin amaç ve görevleri, milli eğitimin genel amaçlarına ve temel ilkelerine uygun olarak,

1. Her Türk çocuğuna iyi bir vatandaş olmak için gerekli temel bilgi, beceri, davranış ve alışkanlıkları kazandırmak; onu milli ahlak anlayışına uygun olarak yetiştirmek;

2. Her Türk çocuğunu ilgi, istidat ve kabiliyetleri yönünden yetiştirerek hayata ve üst öğrenime hazırlamaktır " olarak belirtilmektedir.
}

Bakanlığın 1739 sayılı Milli Eğitim Temel Kanunu'ndaki bu hedeflerini gerçekleştirmek için göreve gelen hükümetlerin eğitimle ilgili programlarında, 8 yıllık zorunlu ilköğretimin başladığ1 55. Türkiye Cumhuriyeti Hükümetinin (1997-1999) eğitimle ilgili hedeflerinin değerlendirilerek başlanması, 2000-2010 dönemine aktarılan eğitim sisteminin alt yapısı olduğu için önemlidir. REFAHYOL Hükümetinin (Refah Partisi ve Doğru Yol Partisi'nin kurduğu koalisyon hükümeti) 30 Haziran 1997 tarihinde sona ermesiyle 30 Haziran 1997 tarihinde Anavatan Partisi (ANAP), Demokratik Sol Parti (DSP) ve Demokrat Türkiye Partisi (DTP) ile (ANASOL-D) koalisyon hükümeti kurulmuştur. Sekiz Yılllk Zorunlu Temel Eğitim Yasası bu hükümet döneminde yasalaştırılan 18 Ağustos 1997 tarihli, 4306 sayılı yasa ile kabul edilerek 1997-1998 öğretim yılında uygulamaya konulmuştur.

\section{0-1940 ve 2000-2010 Dönemlerinin Karşılaştırması}

Yukarıda her dönem kendi içerisinde değerlendirilmiş ve dönemlerde var olan mevzuata açklanmıştır. Açıklanan durum ve mevzuata göre dönemlerin hedefleri arasında benzerlik veya farklılıkların tespit edilmesi için kısa bir karşılaştırma yapmakta yarar vardır.

1930 -1940 dönemi ile 2000- 2010 dönemi hükümet programları karşılaştırıldığında-, 2000-2010 dönemi programlarında 1930-1940 dönemi programlarına göre daha ayrıntılı hedeflerin belirlendiği, hedeflerin uzun uzun anlatıldığı görülmektedir. Her iki dönem programlarında da Türkçenin kullanımına önem verileceği, milli duygu ve değerlerin güçlendirileceği vurgulanırken, her iki dönemde irticai faaliyetlerin, dini duygu ve sembollerin kötü amaçlar için kullanılmasının vurgulandığı görülmektedir. 1930-1940 döneminde milli kalkınma, milli tarih ve dil çalışmalarına, köylünün kalkındırılmasına önem verilmesine ve Osmanlı borçlarının ödenmesi, II. Dünya Savaşına girilmemesi için çaba harcanmasına, az para ile eğitimden fazla yarar elde edilmesi, Türk milliyetçiliğinin, vatanseverliğin güçlendirilmesine vurgu yapıldığı görülmektedir.

$\mathrm{Bu}$ bulgular, ülkenin geleceğini belirleyen, politikaları üreten siyası grupların, özellikle uygulayıcı hükümetlerin, herkesin anlaştığı, kabul ettiği, devlet olarak gelenekselleşen ideolojilerin farklı farklı yorumlandığı hedeflerin doğmasına neden oldukları izlenimi vermektedir. Dolayısıyla hedeflerde uzlaşılamayan bir devlet yapısının dönem dönem değişen insan tipi yetiştirdiği söylenebilir. Aynı zaman diliminde, aynı ortamda yaşamak zorunda kalacak olan farklı hedeflerle yetişen kuşakların, ileride sorunlar yaratması ve yaşaması kaçınılmaz sonuçlar doğuracaktır. Kuşaklar arası çatışmanın yaşandığı ev ortamlarında dahi sorun olabilen farklılaşmanın, demokrasi, hoşgörü ve nitelikli eğitimden geçirilmemiş toplumda sorunsuz uygulanacağını düşünmek gerçekleri zorlamak olarak yorumlanabilir.

Cumhuriyet dönemi eğitiminin temel özelliklerini değerlendiren Akyüz (2013) dönemin siyasal, ekonomik, hukuki, kültürel değişmeleri gerçekleştirildiğinde toplumun \%10'unun bile okuryazar olmaması nedeniyle, değişimlerin kitlelere benimsetilmesinde oynayabileceği rolün her zamankinden fazla anlaşılması nedeniyle eğitime önem verildiğini vurgulamaktadır. Atatürk'ün bizzat kara tahta başına geçerek ders verdiğini, eğitimin laikleştirildiğini, demokratikleştirildiğini, Tevhid-i Tedrisat Kanunu ile öğretimin 
birleştirildiğini, öğretmene değer verilerek eksiğin kapatılması için çalışıldığını vurgulayan Akyüz (2013), 2012'de yönetimde olan hükümetin dindar bir nesil yetiştirmek için ilkokul ve ortaokul programlarına seçimlik Kur'an-1 Kerim, Hz. Muhammed'in Hayatı, Temel Dini Bilgiler adıyla yeni dersler konduğunu, eğitim öğretimde, öz'ün unutulmasına neden olan “şekilsel' tutum ve davranışlara fazla yer verildiğini, zaman zaman hükümetlerin kendi partilerinin isteklerini eğitime aşırı ölçüde yansıttıklarını, bu nedenle istikrarlı bir milli eğitim politikasının izlenemediğini vurgulamaktadır.

1930 'da ilköğretimin çok yüzeysel kalması ve halkın hayatta, çalışmada ihtiyaç duyduğu bilgi ve yetenekleri verememesi başlıca sorun iken; günümüzde öğrencilerin üst kurumlara ve sınavlara değil hayata hazırlanması, sınıfların aşırı kalabalıktan kurtarılması, zorunlu eğitimin 10-12 yıla çıkarılması, öğretmenlik alanı dışından sisteme alınan öğretmenlerin ve sistemdeki diğer öğretmenlerin niteliklerinin yükseltilmesi ve taşımalı eğitim başlıca sorunlardandır (Akyüz, 2013).

Yukarıda açıklanan temel düşüncelerin, Cumhuriyeti sağlam temellere oturtmak ve bu Cumhuriyet içerisinde yaşayacak geleceğin yurttaşları olan öğrencileri yetiştirme olan hedefleri konusunda Özel (2007, v ), Atatürk Dönemi çalışmalarındaki temel eğitim politikasında öğrenci, öğretmen, ders programları, okul konularının her birine ayrı önem verildiğini vurgulamaktadır. Ülke içinde eğitim gören insan sayısını artırmak, kaliteli ve yeterli sayıda öğretmen yetiştirmek, ders programlarını günün şartlarına ve devletin dayandığı temel niteliklere uygun hale getirmek, okulların çeşitli sıkıntılarına son vermek yönünde çalışmalar yapıldığını belirtmektedir.

Yukarıda da değinildiği gibi, 2000-2010 döneminde, 1739 sayılı Milli Eğitim Temel Kanununun genel amaçları belirlenmiştir. Görüleceği gibi, her iki dönemde de belirlenen hedefler doğrultusunda, eğitim politikalarının belirlendiği ve uygulanmaya çalışıldığı görülmektedir.

Öğrencilerin yetiştirileceği program çalışmalarında, 1930-1940 dönemi ile 2000-2010 dönemi hükümet programları karşılaştırıldığında ise, 2000-2010 dönemi programlarında 1930-1940 dönemi programlarına göre daha ayrıntılı hedeflerin belirlendiği, hedeflerin uzun uzun anlatıldığı görülmektedir. Her iki dönem programlarında da Türkçenin kullanımına önem verileceği, milli duygu ve değerlerin güçlendirileceği vurgulanırken, her iki dönemde irticai faaliyetlerin, dini duygu ve sembollerin kötü amaçlar için kullanılmasının vurgulandığ1 görülmektedir. 1930-1940 döneminde milli kalkınma, milli tarih ve dil çalışmalarına, köylünün kalkındırılmasına önem verilmesine ve Osmanlı borçlarının ödenmesi, II. Dünya Savaşına girilmemesi için çaba harcanmasına, az para ile eğitimden fazla yarar elde edilmesi, Türk milliyetçiliğinin, vatanseverliğin güçlendirilmesine vurgu yapıldığı görülmektedir. 2000-2010 döneminde ise bölgesel terör, irticai faaliyetler, dinin kullanımı, laikliğin yorumlanması, eğitimde özel sektörün desteklenmesi, bilişim teknolojilerinin her okula yaygınlaştırılması, e-kitap, tekli eğitim, okul yapımı gibi kavramların sıklıkla kullanıldığı söylenebilir.

Sonuç olarak, eğitim tarihimizde, eğitimi uzun vadeli olarak, bir sistem ve bütünlük içinde ele alıp geliştirme çalışmalarının yapılmadığı, bunlara başlansa da sürdürülüp sonuçlandırılmadığı görülmektedir. Reform, ders programlarının ve not verme sisteminin değiştirilmesi olarak algılandığı için, Tanzimat'tan beri, milli bünyemize ve ihtiyaçlarımıza uygun, bilimsel araştırma verilerine dayanan, kapsamlı, sistemli, istikrarlı düzenleme çalışmalarına ağırlık verilememiştir. Bazı dönemler hariç, niteliğe pek önem verilmemiş, özellikle öğretmen yetiştirme alanında beklenilen uygulamalar çeşitli nedenlerle gerçekleştirilememiştir (Akyüz, 2013).

Amaçlardaki değişikliğin, değişen toplumsal yapının, uluslararası ilişkilerin, küreselleşmenin, $\mathrm{AB}$ uyum çabalarının zorunlu hale getirdiği değişim ve dönüşüm sürecinin, ilköğretim müfettişlerinin okul denetimlerine yansıyıp yansımadığı yapılacak karşılaştırmalarda önemli yer tutacaktır.

\section{Yöntem}

\section{Araştırmanın Modeli}

Bu araştırma nitel bir çalışma olarak tasarlanmıştır. Nitel araştırmalarda olay ve olgulardaki anlam ve gerçeklerin tespit edilmesi ve bir konuya ilişkin derinlemesine bilgi edinilmesi amaçlamaktadır (Denzin ve 
Lincoln, 2005). Bu araştırmada 1930-1940 dönemindeki teftiş raporları ile 2000-2010 dönemindeki aynı okullara ait teftiş raporlarına göre dönemlerdeki öğrenci durumları hakkında bilgi edinmek amaçlanmaktadır. Bu nedenle nitel araştırma yöntemlerinden durum çalışması yöntemi kullanılmıştır. Afyonkarahisar ilindeki 6 ilköğretim okulu durum çalışmasına konu edilmiştir. Veri toplama yöntemi olarak ise durum olarak seçilen okullarda mevcut olan öğrencilerle ilgili yasal dayanaklara ilişkin dokümanlar ve teftiş raporları doküman incelemesine tabi tutulmuştur. Doküman incelemesi, araştırılması hedeflenen olgu veya olgular hakkında bilgi içeren yazılı materyallerin analizini kapsar (Yıldırım ve Şimşek, 2005).

\section{Verilerin Toplanması}

Nitel veriler kelime, resim, belge ve diğer sayısal olmayan bilgilerden oluşmaktadır (Christensen, Johnson ve Turner, 2015). Doküman analizi öncelikli olarak yazılı dokümanları ele almaktadır (Robson, 2015). Bu çalışmada 1930-1940 ile 2000-2010 dönemlerinde öğrencilerle ilgili var olan yasal dayanaklar (yönetmelik, yönerge ve genelge gibi) ve dönemlerdeki uygulamaları günümüze taşıyan teftiş raporları incelenmiştir. Buna göre Türkiye Cumhuriyetinde ilkokul/ilköğretim okulunda kayıtlı olan öğrencilerle ilgili sistemin hedefleri, bu hedefler için belirlenen mevzuatı oluşturan tüm yasal metinler araştırmaya dahil edilmiştir. Bu yasal metinlerdeki değişime göre yönetimin öğrencilere bakış açılarının tespit edilmesi amaçlanmıştır. Bu bakış açısı ile öğrenci durumları ile ilgili yasal metinler üzerindeki değişim, tarihsel olarak olduğu gibi ortaya konulmuştur.

Bu kapsamda Afyonkarahisar İli merkez, ilçe, kasaba ve köy okullarında bulunan 1930- 1940/2000-2010 yılları arasındaki teftiş defterleri veya teftiş tebliğleri veri toplama aracı olarak kullanılmıştır. Veri toplamak amacıyla konuyla ilgili alan yazın taramasının yanı sıra konuyla ilgili yapılmış araştırmalar da incelenmiştir. İlgili yıllara ait teftiş raporları yerinde incelenerek, fotokopileri alınmıştır. Altı okul A, B, C, D, E ve F olarak kodlanmıştır. Bu okullardan alınan teftiş raporlarının sayısı Tablo 2'de yer almaktadır.

Tablo 2. Okullarm Teftiş Raporu Sayıları İle İlgili Veriler

\begin{tabular}{lllllllll}
\hline & A & B & C & D & E & F & N & $\%$ \\
$1930-1940$ & 2 & 9 & 8 & 12 & 5 & 8 & 44 & $\% 47.31$ \\
$2000-2010$ & 7 & 6 & 9 & 9 & 10 & 8 & 49 & $\% 52.68$ \\
Toplam & 9 & 15 & 17 & 21 & 15 & 16 & 93 & $\% 100$ \\
\hline
\end{tabular}

Altı okulda 1930-1940 yılları arasında toplam 44, 2000-2010 yılları arasında ise 49 rapor yazılmıştır. Araştırmada verilerin analizinde betimsel analiz yönteminden yararlanılmıştır. Buna göre yasal metinler ve teftiş raporlarından elde edilen bulgular karşılaştırılarak sistemin öğrencilerden beklentisi ve onlara sağladıkları olanaklar çerçevesinde incelenmiş ve tarihsel süreçte bu beklentilere yönelik değişimler betimsel bir yaklaşımla analiz edilmeye çalışılmıştır.

Afyonkarahisar İli merkez, ilçe, kasaba ve köylerinde bulunan altı okula gidilerek fotokopileri alınan 19301940/2000-2010 yılları arasındaki teftiş raporları incelenerek, elde edilen veriler, doküman incelemesi yöntemiyle analiz edilmiştir. Elde edilen veriler ait olduğu okulun okul kodu önüne, ait olduğu yılın son iki rakamının getirilmesi ile kodlanmıştır. (Örnek: A34 ve A08 gibi)

\section{Verilerin Kodlanması}

$\mathrm{Bu}$ çalışmada okullardan toplanan teftiş raporları araştırmanın başında belirlenen yedi kategoriye göre sınıflandırılmıştır. Okulların adları A, B, C, D, E ve F okulu olarak, yıllar ise son iki rakamı alınarak kodlanmıştır. Teftiş raporlarından tema, kategori ve alt kategorilere aktarılan sözcük veya cümleler ait oldukları yılı ve okulun kodu ile aktarılmıştır. Ancak bazı sözcük ve cümleler başka kategoriyi de ilgilendirdiği için iki, bazen üç farklı kategoride kullanılmıştır. Temalara göre hazırlanan tablolar kendi içlerinde ayrıntılandırılarak kategorilere bazı kategoriler de kendi içlerinde alt kategorilere ayrılmış, böylece araştırmada daha hassas bir analiz yapılması amaçlanmıştır.

Kodlamalar teftiş raporlarındaki tespitlere göre olumlu, olumsuz tespitler ve öneriler olarak Tablo 3 'te yer 
alan örnek tabloda olduğu gibi üç bölümde sınıflandırılmıştır.

Tablo 3. Örnek Kategori Tablosu (Rakamlar ve oranlar rastgele yazılmıştır.)

\begin{tabular}{|c|c|c|c|c|c|c|c|}
\hline \multirow{3}{*}{ Kategoriler } & \multicolumn{5}{|c|}{ Dönem } & & \multirow[t]{3}{*}{ Toplam } \\
\hline & \multicolumn{3}{|c|}{$30-40$} & \multicolumn{3}{|l|}{$00-10$} & \\
\hline & $\overline{\mathrm{Om}}$ & Os & Ön & $\mathrm{Om}$ & Os & Ön & \\
\hline Atatürkçülük Köşesi & - & - & - & 40 & - & 2 & $42 \% 59.15$ \\
\hline $\begin{array}{l}\text { Türk Bayrağ1 mevzuatı } \\
\text { töreni }\end{array}$ & $\mathrm{e}_{-}$ & - & 1 & 21 & - & & $22 \% 30.98$ \\
\hline Tespitlerin toplamları & 2 & 1 & 5 & 61 & - & 2 & $71 \% 100$ \\
\hline Tespitlerin oranları & $\% 25$ & $\% 12.5$ & $\% 62.5$ & $\% 96.82$ & - & $\% 3.17$ & \\
\hline Genel toplamlar & & $8 \% 11.26$ & & & $\% 88.7$ & & \\
\hline
\end{tabular}

\section{Bulgular ve Yorumlar}

Araştırmanın bu bölümünde Afyonkarahisar'ın İl merkezi, kasaba ve köylerinde bulunan altı ilköğretim okulunda bulunan 1930-1940 ve 2000-2010 yıllarına ait teftiş raporlarının çözümlenmesinden sistemin öğrenciye bakışına ilişkin elde edilen bulgular ve yorumlar yer almaktadır.

\section{Alt problem 1: Sistemin Öğrenciye Bakışı}

Sistemin öğrenciye bakışına ilişkin temel yaklaşımlar, benzerlik ve farklılıklar içerisinde bireysel farklılıklar, öğrenci merkezli ders işlenmesi, öğrenci sağllğı ve öğrenci davranışları/disiplin işleri olmak üzere dört kategori yer almaktadır. Kategoriler Tablo 4'te verilmiştir.

Tablo 4. Müfettişlerin sistemin öğrenciye bakışına ilişkin tespitlerinin kategorilere göre dă̆ılımı

\begin{tabular}{|c|c|c|c|c|c|c|c|}
\hline \multirow[t]{3}{*}{ Kategoriler } & \multicolumn{5}{|c|}{ Dönem } & \multirow{3}{*}{\multicolumn{2}{|c|}{ Toplam }} \\
\hline & \multicolumn{2}{|l|}{$\overline{1930-1940}$} & \multicolumn{3}{|c|}{$2000-2010$} & & \\
\hline & Olm & Ols & One & Olm & Ols & & \\
\hline Bireysel farklılıklar & 2 & 1 & 14 & 2 & - & 10 & $29 \% 44.61$ \\
\hline 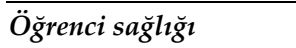 & 6 & 1 & 6 & - & - & 3 & $16 \% 24.61$ \\
\hline Öğrenci davranışları & 1 & - & 4 & 1 & - & 14 & $20 \% 30.76$ \\
\hline Tesptilerin toplamlan & 9 & 2 & 24 & 3 & - & 27 & \\
\hline Tespitlerin oranları & $\% 25.71$ & $\% 5.71$ & $\% 68.57$ & $\% 10$ & $\% 0 \% 90$ & $\% 90$ & \\
\hline Gene toplamlar & $35 \% 53.84$ & & & & $30 \% 46.15$ & & 65 \\
\hline
\end{tabular}

(Olm: Olumlu tespit, Ols: Olumsuz tespit, One: Müfettiş önerisi)

Sistemin öğrenciye bakışı teması ile ilgili olarak Tablo 4'te yer alan bulgular incelendiğinde 1930-1940 döneminde toplam 35 (\%53.84) tespit ve önerinin yer aldı̆̆ı görülmektedir. 2000-2010 döneminde ise toplam $30(\% 46.15)$ tespit önerinin yer aldığı anlaşılmaktadır. Bu sonuçlara göre her iki dönem müfettişlerin, miktarları değişse de öğrencilerin bireysel farklılıkları, öğrenci sağlığı ve davranışları ile ilgili tespit ve öneri yaptıkları, 1930-1940 dönemi müfettişlerinin ağırlıklı olarak öğrenci sağlığı ve bireysel yetersizlikleri ile ilgili fazla sayıda tespit ve öneri yaptıkları, 2000-2010 dönemi müfettişlerinin ise öğrenci davranışları/disiplin, BEP (Bireyselleştirilmiş Eğitim Programı) ve SBS (Seviye Belirleme Sınavı yeni adı TEOG, LGS) kursları da dahil olmak üzere öğrencilerin bireysel farklılıkları üzerinde durdukları söylenebilir.

\section{Alt problem 2: Öğrencilerin Bireysel Farklılıklar}

Tablo 4 incelendiğinde öğrencilerin bireysel farklılıkları kategorisi ile ilgili 1930-1940 döneminde iki olumlu (\%11.76), bir olumsuz (\%5.88) ve 14 öneri (\%82.35) olmak üzere 17 tespit (\%100) ve öneri yapıldı̆̆ görülmektedir. 2000-2010 döneminde ise iki olumlu (\%16.66) tespit ve 10 öneri (\%83.33) olmak üzere toplam 12 tespit ve öneri (\%100) yaptıkları anlaşılmaktadır.

Bireysel farklılıklar kategorisinde öğrencilerin bireysel başarı durumları ile ilgili olarak 1930-1940 döneminde görev yapan müfettişlerin 2000-2010 döneminde görev yapan müfettişlere göre daha duyarlı 
oldukları söylenebilir. Bunun nedeninin, 1930-1940 dönemi müfettişlerinin sınıf denetimlerinde sinıfta bulunan öğrencilerle ilgili bireysel veya sınıflar düzeyinde daha ayrıntılı gözlem yapmalarına bağlı olarak, öğrenci sayı veya oranlarını tespit etmeleri olduğu söylenebilir.

Araştırmada elde edilen bulgulara göre 1930-1940 döneminde C32 raporunda "İyi derecede geliştirilen talebe, mevcudun üçte ikisi nispetindedir. Fikri inkişaf vardır" tespiti yer almaktadır. Bu tespit ile sınıfın genel bir değerlendirilmesinin yapıldığı, olumlu ve aynı zamanda olumsuz yönlerinin rapora aktarıldığı, müfettişin, kişisel görüşünü yansıttı̆̆ görülmektedir. F36/5 raporunda ise aynı dil kullanılarak "Talebe genel görünüşleri ile ileri seviye gösterememişlerdir. Hele Hayat Bilgileri ve zihni hesapları sinıflar seviyelerinden aşağı bulunmuştur" denilerek olumsuz tespitin yer aldığı, bu olumsuz tespit ile teftiş edilen sınıfın, genel durumunun ve özellikle Matematik dersi ile Hayat Bilgisi dersi konularının programın hedeflediği seviyeden aşağıda bulunduğu belirtilmektedir. Bu yaklaşımla müfettişin programa hâkim olduğu da ortaya çıkmaktadır.

Benzer diğer tespitlerde ise A36 yılı raporunda "Üçüncü sınıf çocukları kadar ikincilerin de yetiştirilmesini öğretmen Muharremden beklerim, B38 raporunda "Sinıfların seviye düşüklüklerini telafi ve ikmal etmek için tedbirler alınmasın işlerine candan ilgili arkadaşlardan bekler başarılar dilerim", D33 raporunda "Aynı sinıfta takviyeye muhtaç görünen talebe üzerinde kısmi ferdi tedrisat yapılması ve ameli hesapların takviyesi", E39/2 raporunda "Birinci stnıf iki guruptur. Illeri gurup (20) kadardır. Geri guruba da zamanlarndan ayırarak ders verelim" denilmektedir.

Araştırmada, 2000-2010 döneminde ise müfettişlerinin olumsuz tespit yapmadan iki olumlu tespit ve 10 öneride bulundukları görülmektedir. Öğrencilerin akademik başarıları ile ilgili iki tespit yapıldığı, bu tespitlerin de Seviye Belirleme Sınavlarına (SBS, sonraki adı TEOG, güncel adı LYS) katılma ve bu sınavlardaki başarı oranlarından oluştuğu görülmektedir. E10 raporunda yapılan tespitte "Okulda SBS'ye yönelik kursların düzenlendiğ $i$ ", B09 raporunda yer alan tespitte de "Geçen yıl SBS sonuçlarına göre ortaöğretim kurumlarına 22 öğrenci yerleştirildiğgi, ilçe sıralamasında 6. Sinıflarda 1., 7. sinıflarda 2. sırada yer aldığı, Halk Ĕ̆itim Merkezi (HEM) İşbirliği ile İlçe çapında düzenlenecek SBS. sinavlarına hazırlık kurslarn için 6,7 ve 8. sinıflardan toplam 50 öğrencinin isimlerinin ilçe MEM. 'ne bildirildiği" belirtilmektedir.

Önerilerde yer alan A05 raporunda yer alan “Özel eğitime ihtiyacı olan öğrenciler için çalışmaların planlanarak uygulanması" önerisinin A04, C07, D08, E03 ve F03 raporlarında da tekrarlanarak, sınıf seviyesine göre açık yetersizliği olan öğrenciler için önlem alınması önerilmektedir. Bu önerinin A10 raporunda olduğu gibi İlköğretim Kurumları Yönetmeliği (IKKY) 47'nci maddesine vurgu yapılarak mevzuatın hatırlatıldığı görülmektedir. A10 raporunda "IK Yönetmeliğinin 47. Maddesine göre sinıf seviyesine göre başarıları düşük öğrenciler için gerekli önlemlerin alınması" önerisi yer almaktadır. B09 raporunda yer alan "BEP (Bireyselleştirilmiş Eğitim Programları) biriminin oluşturularak kaynaştırma programına alınan öğrenciler için BEP planlarının yapılması (2567 Sayılı T.D. ve MEB 2004/7 sayıl genelge), kaynaştırma eğitimine tabi 1. ve 2. sinıftaki 2 öğrenciye destek eğitimlerinin, okulun eğitim-öğretim saatleri dışında verilmesinin temini." önerisi ile BEP programının uygulanması, D08 raporunda da Rehberlik ve Araştırma Merkezi ile iş birliği yapılması önerilmektedir.

Dönemlerin mevzuatı incelendiğinde, bu alanla ilgili olarak her iki dönemde de mevzuat bulunduğu anlaşılmaktadır. 2000-2010 döneminde var olan İKY'nin 47 nci maddesine göre, öğrenme güçlüğü çeken, zihinsel ve fiziksel yetersizliği olan öğrenciler için BEP'nın hazırlanması istenirken, 1930-1940 dönemi mevzuatı olan İlkmektepler Talimatnamesinin üçüncü maddesinde 1930 yılında yapılan değişiklikle:

\footnotetext{
"Bedence anormal olanlardan şunlar ilkmekteplere kabul edilmezler: İki gözü kör olanlar, yüksek sesle söylenen sesleri işitemeyecek derecede ağır sağır veya dilsiz olanlar. Bunlardan başka bedeni (kaza, bela) avariz kabule mani değildir. Sâri (bulaşıcı) ve müstekreh (iğrenç) hastalıklar "mesela: yaralı kel " kabule manidir. Ruhen anormal olanlardan ağır derecede belahet (alıklık) tezahürü gösterenler kabul edilmez. Bir çocuğun harici hal ve hareketinde görülecek sarsaklık ve muvazenesizlik (dengesizlik) belahetin ilk nazara çarpan alametidir. Böyle olan çocuklar için şöyle bir muayene yapılarak belahet dereceleri tayin olunabilir. Kendisinin adı sorulur; bir elindeki parmakla birer, ikişer, ayrı ayrı bir arada saydırılmak suretiyle ta'dat (sayma) kabiliyeti yoklanır. Bu muayeneye sihhatle cevap veremiyenler ruhan anormal sayılarak mektebe alınmazlar" hükmü yer almaktadır.
}

2000-2010 döneminde de 2004 yılı Kasım ayında 2566 sayılı Tebliğler Dergisinde yayımlanan ve daha sonra 2008, 2012 ve 2014 yıllarında yeniden değişiklik yapılan İlköğretim Kurumlan Yönetmeliği'nin 47'nci maddesinin (e-) fıkrasında "Kaynaştırma ve özel eğitim sınıflarında eğitimlerine devam eden öğrencilere, 
başarısızlıklarından dolayı sınıf tekrarı yaptıılmaz. Bu öğrencilerin başarısının tespiti, 31/5/2006 tarihli ve 26184 sayılı Resmî Gazete'de yayımlanan Millî Eğitim Bakanlığı Özel Eğitim Hizmetleri Yönetmeliği hükümlerine göre yapılır" ibaresinin yer aldığı görülmektedir. Aynı yönetmeliğin beşinci maddesinde, özel eğitime ihtiyacı olan bireylerin, toplum içindeki rollerini gerçekleştiren, üretici ve mutlu bir vatandaş olarak yetişmelerinin, bağımsız yaşamaları ve kendi kendilerine yeterli bir duruma gelmelerine yönelik temel yaşam becerilerini geliştirmelerinin, uygun eğitim programları ile özel yöntem, personel ve araç- gereç kullanarak; eğitim ihtiyaçları, yeterlilikleri, ilgi ve yetenekleri doğrultusunda üst öğrenime, iş ve meslek alanlarına ve hayata hazırlanmalarının amaçlandığı görülmektedir.

\section{Alt problem 3: Öğrenci Sağlı̆̆ı}

Tablo 4 incelendiğinde 1930-1940 döneminde altı (\%46.15) olumlu tespit, bir (\%7.69) olumsuz tespit ve altı (\%46.15) öneri yapıldığı; 2000-2010 döneminde ise sadece üç (\%100) öneri olmak üzere toplam 16 tespit ve öneri yapıldığı görülmektedir. Bulgulara göre 1930-1940 dönemi müfettişlerinin öğrenci sağlığı kategorisine daha fazla önem verdikleri söylenebilir.

Öğrenci sağlığı ile ilgili olarak Tablo 4'te yer alan bulgular incelendiğinde, 1930-1940 döneminde yapılan tespit ve önerilerin içeriğinin öğrencilerin sıhhi bakımları, temizlik alışkanlıkları, diş, saç, kıyafet olmak üzere vücut temizliği ve bakımından oluştuğu, 2000--2010 döneminde ise taşımalı eğitim sistemi ile taşınan öğrencilerin yemek, yemekhane ve bu işle görevli personelin temizliğinden oluştuğu görülmektedir.

1930-1940 döneminde B okuluna ait 1937,1937-2,1938 raporlarında ve D37-12 raporunda "Çocukların bakımı iyi," "Çocukların diş bakımına dikkat edilmesi", 1938 raporunda "Ekseriyasının diş firçası vardır", 1939 raporunda "Çocukların bazılarının diş bakımı ve mendil kullanma alı̧kanlığı noksan, bitli olanlar da var, ama genel olarak bakım ve düzen iyi" tespitlerinin D okuluna ait 1938 raporunda "Okul temiz ve düzenli, öğrenciler de böyle temiz olmah", 1937-12 raporunda "Mendil kullanma alışkanlığg verilmeli, yapılan ev tetkiki bir eve gidilerek yapılsaydı daha iyi olurdu" tespitinin yer aldığı, E okulunun 1934 raporunda "Çocuklarm temizliği her gün olmalı", 1938 raporunda "Çocuklara yaptırılan tek tip kıyafet ve kızların saçlarını kestirmenizden memnun oldum. Çocukların temizlikleri de iyi. Diş bakımı ve mendil kullanma alı̧̧kanlığı da verilmeli" tespitleri yer almaktadır.

Özellikle müfettişler tarafından yazılan F33 raporunda yer alan "Saçların taranması için birkaç tarak, bir ayna tedarik etmek" tespiti dönemin şartlarını tam olarak açıklamaktadır. Yapılan bu tespit sadece müfettişlerin kişisel gözlemi değildir. Yokluk ve bakımsızlık, dönemin mevzuatında da yer almıştır. Dönemin mevzuatı olan İlkmektepler Talimatnamesinin 34 üncü maddesinde:

\footnotetext{
"Talebenin kıyafetçe mutlaka yeknasak olmaları lazım değildir. Çocuk velilerine ağırlık vermemek şartiyle kıyafet birliği teminine imkân bulunursa tabii iyi olur. Böyle bir çare bulunmıyan hallerde kıyafetlerin yalnız temizliği, çalışmağa, koşup oynamağa müsait ve sıhhi olmasına dikkat etmelidir. Oğlan çocuklar için kısa bir pantalon, yazın bolca bir bulüz veya gömlek, kışın kalınca bir ceket hafif bir kasketi sağlam ve ayağa uygun bir çift iskarpin ile kalınca, uzun konçlu çorap çok elverişlidir. Bu kıyafet kızlarda yalnız pantalon yerine eteklik giyilmesi şeklinde bir tadile uğrar, kasket yerine bere de kızlar için daha gösterişlidir. Kızlar için koyu renkli bir göğüslük hem ucuz, kullanışlı, hem de yapılışa göre pek zarif olabilir. Mektep kıyafeti için milli mamulatın tercihi şartıı." denilmektedir.
}

Talimatnamenin 156. Maddesinde:

“Diş bakımına hasseten itina edilmelidir. Dişlerin korunması için talebeye sık sık telkinlerde bulunmalı, bilhassa diş fırçasının layıkiyle istimali öğretilmelidir. Bunun için mümkün olursa dershanede fırça talimleri yaptırılması münasip düşer. Senede en az dört defa diş muayenesi yapılmalı ve dişlerine ihtimamda kusuru görülen talebeye ve icabederse velisine ihtarda bulunulmalıdır" derken,

157. Madde "Saçlara ihtimam ciheti de unutulmamalıdır. Haftada bir defa saç yoklaması yapılmalı ve çocuklar her hafta başlarını yıkamağa ve saçlarını kestirmeğe teşvik edilmelidir. Her sabah temizlik yoklaması yapılmalıdır. Vücutlarında, başlarında yara görülen çocuklar hemen muayene ettirilmelidir." denmektedir.

Görüleceği gibi dönemin mevzuatı var olan sorununun çözümü için ayrıntılı olarak yapılması gerekenleri vurgulamakta, yol göstermekte ve aynı zamanda öğretmenlerin çalışma şartlarını da açıklamaktadır. Öğrencilerin temizlik alışkanlığı kazanmaları için yapılan çalışmalarla ilgili yayınlanan 22/12/1941 tarih ve 14970/742 sayılı "Talebe Temizlik Yoklamalarına İtina Edilmesi" başlıklı tamimden anlaşılacağı gibi bu 
konuda öğretmenlerin duyarsızlık gösterdiği, öğrenci sağlığının önemine uygun davranmadıkları anlaşılmaktadır.

\begin{abstract}
"İlkokullar Talimatnamesinin 157'-nci maddesi, okullarımızda her sabah temizlik yoklamasını amir olduğu halde bazı mahallerde bu hususa layıkı veçhile itina edilmediği anlaşılmaktadır. Terbiye yuvası okullarımızda çocuklarımıza küçük yaşta sıhhi itiyatlar kazandırılması lazım geleceği aşikârdır. Bunun için her şeyden önce her sabah, talimatnamenin de emrettiği üzere, çocukların temizlik muayenesi yapılacak, sıhhi ve medeni icaplara riayette geri kalanlar varsa, velileriyle iş birliği yapılarak bunlar bu fena itiyatlarından vazgeçirilinceye kadar, bıkmadan, usanmadan çalışacaktır. Öğretmen arkadaşlarımdan talimatname hükümlerine harfiyen riayet etmelerini bekler, yapılacak teftişlerde bu hususta hiç kimsenin ihmal ve müsamahasını görmek istemediğimi tebliğ ederim"
\end{abstract}

denilerek tamimin son bölümünde de müfettişlerin bu konudaki görevleri hatırlatılmış, konunun ne kadar önemli olduğu vurgulanmıştır.

2000-2010 dönemi teftiş raporlarında öğrenci sağlığı ile ilgili yazılan iki olumlu tespitte, B03 raporunda "Taşımalı öğrencilere Millı̀ Ĕ̆itim Bakanlığınca sıcak yemek verildiği" ve B09 raporunda "Taşınan öğrenciler için yemek odası düzenlendiğ $i$, sıcak yemek verildiğ $i$ " tespitlerine yer verilmektedir. 2000-2010 dönemi B09 raporunda "Taşımalı Öğrencilere yemek servisi yapan kişinin eldiven, bone, önlük ve maske kullanması, öğrencilere temizlik ve sağlık eğitiminin verilmesi" ve C00 raporunda "Taşımalı olarak gelen öğrencilerin daha temiz ortamlarda yemek yemelerinin sağlanması" ifadelerinin yer aldığı; B09 raporunda "Öğrencilere temizlik ve sağlık eğitiminin verilmesi" önerisi dışında başka bir tespit veya öneriye rastlanmadığı görülmektedir.

İlköğretim okulu bulunmayan veya çeşitli nedenlerle eğitim-öğretime kapalı, birleştirilmiş sınıf uygulaması yapan ilköğretim okullarındaki öğrencilerin, kaliteli bir eğitim- öğretim görmeleri amacıyla 15/04/2000 tarih ve 24021 sayılı Resmî Gazete yayınlanan Millî Eğitim Bakanlığı Taşımalı İlköğretim Okulu Yönetmeliğinin 1'inci maddesine göre taşıma merkezi ilköğretim okullarına günü birlik taşınacağ belirtilmektedir. Bu dönem İlköğretim Kurumları Yönetmeliğinin "İlköğretimin Amaçları" bölümünde yer alan 5 inci maddesinin (g) bendinde öğrencilere, toplumun bir üyesi olarak kişisel sağlığının yanı sıra ailesinin ve toplumun sağlığını korumak için gerekli bilgi ve becerinin, sağlıklı beslenme ve yaşam tarzı konularında bilimsel geçerliliği olmayan bilgiler yerine, bilimsel bilgilerle karar verme alışkanlığının kazandırılmasının amaçlandığı, yine aynı yönetmeliğin 139 uncu maddesinde öğrenci sağlığı ve güvenliği hizmetlerinin yürütülmesinde, okul ve çevre sağlı̆̆ı, periyodik aşıların yaptırılması, fakir öğrencilerin gözetilmesi, okulda beslenmede dikkat edilecek hususların sıralandığı, taşımalı öğrencilerin yemek işlerinin açıklandığı görülmektedir.

Cumhuriyetin başlangıç dönemini oluşturan 1930-1940 döneminde toplumun yokluk ve bilgisizlikten kaynaklanan kişisel bakım eksikliğinin, eğitmen veya öğretmenler aracılığı ile giderilmeye çalışıldığı; günümüz çocukları ve aileleri için sıradan bir davranış olan öz bakım becerilerinin, okul öncesi eğitim programlarında da yer aldığı, 2000-2010 dönemi raporlarında da bu konularda herhangi bir tespitin yapılmadığı görülmektedir. Ancak az da olsa günümüz Türkiye'sinde okullarda bit salgınına ait vakalarının görüldüğü, 2012 ve 2013 yıllarına ait basında yer alan haberlerde, Diyarbakır ve Şanlıurfa'nın bazı okullarında rastlanan bit salgının okul idareleri tarafından ailelere bildirildiği, ancak Millî Eğitim Müdürlüklerine bildirilmediği, dolayısıyla resmi olarak işlem yapılmadığı anlaşılmaktadır ("Urfa'da Okullarda", 2013; "Okullarda bit salgını", ).

Diğer yandan televizyon haberlerine de yansıyan ve öğrencilerin merkezi seçme sınavına hazırlıklarında ortaya çıkan eksikliklerini gidermek için gittikleri dershane borcunu ödeyemeyen aile dramlarının da yaşandığı ("Para ödendi", 2012) bir eğitim sisteminden, sınav odaklı eğitim anlayışından, ilköğretimin temel hedeflerine uygun, yurttaş yetiştirme hedefine uygun eğitim yapan eğitim sistemine yeniden dönülmesi gerekmektedir.

\title{
Alt problem 4: Öğrenci Davranışları ve Disiplin
}

Bu kategoride 1930-1940 ve 2000-2010 dönemlerinde uygulanan öğrenci davranışları ve disiplin uygulamalarına ilişkin bulguların karşılaştırması yapılarak benzerlik ve farklılıkların tespit edilmesine çalışılmıştır. 
Tablo 4 incelendiğinde her iki dönemde birer (\%10) olumlu tespit ve 18 (\%90) öneri yapıldığı görülmektedir. 1930-1940 döneminde beş (\%20) tespit ve öneri yapılırken, 2000-2010 döneminde toplam 15 (\%80) tespit ve öneri yapıldığı görülmektedir. Dönem içi değerlendirmede ise 1930-1940 döneminde yapılan bir (\%20) olumlu tespit ve dört (\%80) öneriye rağmen 2000-2010 döneminde bir (\%6.66) olumlu tespit ve 14 (\%93.33) öneri yapıldı̆̆ı görülmektedir.

Bulgularda 2000-2010 döneminde "Soru sorma, açılama yapma ve söz alma gibi olumlu toplumsal davranışların kazandırılmasında gösterilen çabaların artırılması" ifadesinin dokuz kez "Öğrencilerin okul ve sinıf kurallarına uyumu üzerinde durulması" üç kez tekrarlandığı görülmektedir. Bulgulara göre öğrenci davranışları konusuna 2000-2010 dönemi müfettişlerinin 1930-1940 dönemi müfettişlerine göre daha çok tespit ve öneri yazdıkları anlaşılmaktadır.

1930-1940 dönemi teftiş raporlarına göre C32 raporunda olduğu gibi öğrencilerin okul kurallarını iyi öğrendiği belirtilmektedir. A30 ve D34/12 raporlarında "bahçenin ve bahçede öğrencilerin kontrol altında tutulması", A31 raporunda "öğrencilerin okul eşyaların tasarruflu, temiz ve düzenli kullanmalarının să̆lanması", B37 raporunda "birinci sımıfta kuralların oluşturulması" önerilmektedir.

A31 ve C33/4 raporlarında öğretmen tarafından öğrenciye sınıf içi şiddetin yapılmaması önerilmektedir. C33/4 raporunda "Sizden beklediğim iş, okul hayatında hiddet, şiddet ve falaka olmaması, sakin ve şuurlu davranmaktır. Varsa bu davranışın terk edilmesi" yönündeki önerisi ve A31 raporunda yer alan "Sinıfta daha uygun bir disiplin olmasını isterim. Hiddet ve asabiyet fışkıran bir ses, bă̆rışma ve yüksek söylenme çocuğu daha arsız ve yüzsüz yapar. Aksi halde sinıfta disiplin tesis edilemez" tespiti dikkat çekicidir. 1930-1940 döneminde yapılan dört öneriden ikisinin (A31, C33/4) öğretmenlerin disiplin anlayış ve uygulamalarına dönük eleştiriler olması, dönemin disiplin anlayışına ışık tutmaktadır.

2000-2010 döneminde ise A00, B00, E03 raporlarında "Öğrencilerin okul malını dikkatli kullanmaları ve okul ve sımıf kurallarına uyumu üzerinde durulması" önerilerde okullardaki ders araç gereçlerinin kullanımı ve okul kurallarına uyum üzerinde durulması, günümüz öğrenci davranışları konusunda bilgi vermektedir. Bu dönemde yapılan önerilerde çoğunlukla A05, A08, C05, D01, D04, D05, E05, F00, F01 raporlarında yapılan öneri ve öz olarak bu öneriye benzeyen diğer önerilerin yer aldığı görülmektedir. E05 raporunda "Öğrencilere, söz alma, dinleme, kendini ifade etme gibi temel becerilerin kazandırllması, bu davranışların derslerle ilişkilendirilerek pekiştirilmesi" önerilmektedir.

\section{Tartışma ve Öneriler}

1930-1940 yıllarında görev yapan ilköğretim müfettişleri ile 2000--2010 yıllarında görev yapan ilköğretim müfettişlerinin eğitimin temel boyutlarına ilişkin tespitlerini analiz ederek 70 yıl gibi uzun bir aralığa dayalı eğitimin iki döneminin karşılaştırılmasına; elde edilen bulgulara ve değerlendirmelere dayanarak, eğitim sistemimizde geçmişten günümüze kadar geçen süreçte nelerin değiştiği, nelerin korunduğunun tespit edilmesine çalışılmıştır.

Bu amaçla, Afyonkarahisar ili ilköğretim okullarının (ilkokulların) 1930-1940 ve 2000-2010 yıllarına ait teftiş raporlarında müfettişler tarafından tespit edilen eğitim sorunları ve bu sorunların çözümüne yönelik olarak yapılan öneriler, Cumhuriyet ideolojisinin yükseliş dönemine denk gelen 1930-1940 arası ile Cumhuriyet'in olgunluk dönemine denk gelen 2000-2010 arasını karşılaştırmak Cumhuriyet ideolojisinin ve bu ideolojinin geçirdiği evrimi analiz etmemize yardımcı olacaktır.

Her iki döneme hâkim olan eğitim felsefesi, eğitime etki eden siyasal ve ideolojik bakış açları, toplumsal yapı ve dinamikler boyutlarında sistemin öğrenciye bakışında benzerlik ve farklılıkların neler olduğunu bulmaya yönelik bir karşılaştırmanın yapılmasına olanak sağlayacaktır. Bu düşünceden hareketle yapılan araştırmada ilginç tespitlerin ve değerlendirmelerin yapıldığı görülmektedir.

Araştırmada, müfettişler tarafından yapılan tespitlere göre 1930-1940 döneminde müfettişlerin ders denetimlerine özel önem verdikleri, sinıflarda gördükleri olumlu ve olumsuz durumlar ile sorunların giderilmesi için önerilerini açık olarak yazdıkları görülmektedir. Okuma yazma, zihinden hesap gibi temel 
bilgilerin eksikliğinin olduğu görülen sınıflar ve sınıf seviyesinin altındaki öğrencilere ilgili eksiklerin giderilmesi için özel ders verilmesi ve zaman ayrılmasının tavsiye edildiği, öğretmenleri cesaretlendirmeye, onlara moral vermeye çalışıldığı görülmektedir. 1930-1940 döneminde dönemin şartlarına göre okula kaydı yapılacak özel durumu olan öğrencilerin eğitimi için özel bir hüküm yer almasa da, okulda diğer normal öğrencilerle birlikte öğrenim görebilmesi için düzenleme yapıldığı anlaşılmaktadır

2000-2010 döneminde ise sınıf seviyesi altında olan veya açk yetersizliği olan öğrencilerin tespit edildiği, eksikliğin giderilmesi için özellikle var olan mevzuatın uygulanarak önlem alınması istenmektedir. Dönemin yasal düzenlemelerinde özel durumu olan öğrenciler için mevzuat ve bu mevzuat doğrultusunda özel programlar hazırlandığı, özel hizmet birimlerinin oluşturulduğu, bu amaçla özel merkezler kurulduğu görülmektedir.

Elde edilen bulgulara göre 1930-1940 dönemindeki öğrenci sağllğı bölümünde öğrencilerin temizlik, bakım gibi temel sağlık durumlarının öğretilmesi ve geliştirilmesi konularından oluştuğu, 1930-1940 döneminde il merkezinde bulunan okul dışında kalan kasaba ve köy okullarında, öğrencilerin çok olumsuz sağlık şartlarında yaşadıkları söylenebilir. Elde edilen bulgulara göre, 1930-1940 döneminde yapılan tespit ve önerilerin içeriğinin öğrencilerin sıhhi bakımları, temizlik alışkanlıkları, diş, saç, kıyafet olmak üzere vücut temizliği ve bakımından oluştuğu, 2000-2010 döneminde ise taşımalı eğitim sistemi ile taşınan öğrencilerin yemek, yemekhane ve bu işle görevli personelin temizliğinden oluştuğu görülmektedir.

Kasaba ve köylere öğretmenlerin gelmesinin toplum sağlığı açısından ne kadar önemli olduğu, öğretmenlerin eğitim işleri dışında nelerle uğraştıkları, bugünkü öğretmen görevleriyle karşılaştırıldığında daha da belirgin hale gelmektedir. Dönem müfettişlerinin raporlarına yansıyan diş firçalama, saç tarama alışkanlığı, temiz giyinme, bitten arınma, günlük bakım gibi öz bakım becerileri ile ilgili önerileri dönemin yaşam biçimi açısından düşündürücüdür.

Sınıf içi şiddet, gerginlik kaynakları ve okul ve sınıf içi disiplinde olumlu ve olumsuz öğrenci davranışlarının kaynakları ile ilgili yapılan araştırmalar ve değerlendirmelere göre aile, çevre, arkadaş çevresi ve öğretmenlerin tutumlarının öne çıktığı vurgulanmaktadır. Küçükahmet (1999), öğretmenin sınıf içinde sesini kullanmayı bilmesi gerektiğini vurgulamakta; Erçıktı (2009) ise, genel olarak öğretmenin ders anlatırken ses tonunda bir değişiklik olmamasının, monoton ders anlatılmasının disiplinsiz davranışların nedenleri arasında yer aldığını belirtmektedir.

Alanyazında yer alan bu saptamalara paralel olarak 2000-2010 dönemi raporlarında yer alan "Öğrencilere, söz alma, dinleme, kendini ifade etme gibi temel becerilerin kazandırılması, bu davranışların derslerle ilişkilendirilerek pekiştirilmesi" önerisi tek başına bu dönem eğitim sistemimizin içinde bulunduğu durumu göstermesi açısından önemlidir. Toplumda yaşanan iletişim sorunlarının kaynağının daha alt kademelerde ortaya çıktığı, önlenmesi için eğitimcilerin uyarıldığı, yapılan 14 öneriden sekizinin bu içerikte olduğu, bu nedenle de ailelerin, öğretmenlerin, okul yöneticilerinin ve eğitim politikalarını belirleyen hükümetlerin üzerinde çalışmaları gereken bir konu olduğu anlaşılmaktadır.

Öğrenci davranışlarını şekillendiren kuralları içeren 1930-1940 dönemindeki İlkmektepler Talimatnamesi ile 2000-2010 döneminde var olan İlköğretim Kurumlan Yönetmeliğinin birbirine bu açıdan benzerlik gösterdiği, ancak, 2000-2010 döneminde okul değiştirme cezasını gerektirecek davranışların tanımlanmasında şiddet, tehdit, siyasi eylem, alkol kullanımı, taciz vb. tür eylemlerin yer alması, bu dönemde okulların ve toplumun karşı karşıya olduğu tehlikeyi göstermektedir.

Bu aşamada yanlış başlangıç yapıldı da sonuç bu nedenle mi böyle oldu? sorusuna cevap bulmak için sistemin kuruluşunu incelemekte yarar vardır. 1930-1940 döneminin özel şartları içerisinde kurulmaya çalışılan eğitim sisteminin temellerinin atılması, en kısa sürede köye ve köylüye ulaşılarak, temel insani değerlerin kazandırılması için yoğun bir çalışma yapıldığı, bu çalışmada acele edilmeden ancak ihtiyaçların tespit edildiği ile ilgili olarak dönemin Başbakanı İsmet İnönü, 08/11/1928 günü, Türkiye Büyük Millet Meclisinde yaptığı konuşmada "İlk tahsili fiilen umumi bir hale getirmek meselesini enine boyuna ve çok özen ile tetkik ettik. ... bütün memlekette bir plana göre mütevazi fakat sıhhi, temiz ihtiyaca kafi binalarla ilk tahsili 
bütün vatana fiilen umumi kılmak mümkün olacaktır. Tetkikatımız seneler sürdü" (TBMM, 8 Kasım 1928, 3.Dönem, 2. Yasama Yılı, 5. Cilt, 3. Birleşim, s. 26-29, Aktaran Öztürk, 1968) diye açıklama yapmaktadır.

Bu şartlarda temellenen eğitim politikalarında 1936 ilkokul programı ile oluşturulması düşünülen ulusal eğitimin hedefleri ana başlıklar halinde şu şekilde sıralanmaktadır (Edis, 1947):

A) Eğitim siyasamızda temeltaşı bilimsizliği gidermektir. Kültür işinde, her gün daha çok çocuk ve yurtdaş okuyup yetiştirecek bir program güdülecektir. Bu düsturun ifade ettiği gayeyi tahakkuk ettirmek için ilkokul öğretmeni kendine düşen ödevi yapmalı, bulunduğu yerde okumamış, yetişmemiş yurtdaş bırakmamağı iş edinmelidir.... Hasılı okul öğretmeni, okulu, bulunduğu yerin eğitim ihtiyacını temin edecek esaslı ve verimli bir ocak haline getirmek için elinden ne gelirse yapmalıdır. Cumhuriyetin kendisine verdiği ödevi yerine getirmiş olmıyacağını bilerek ona göre canla başla çalışmalıdır.

B) Kuvvetli Cumhuriyetçi, ulusçu, halkçı, devletçi, laik ve devrimci yurtdaş yetiştirmek bütün öğretim derecelerinde yüküm ve özen noktasıdır. «Türk ulusunu, kamutayı ve Türk Devletini sayın tutmak ve tutturmak, bütün yurtdaşlara bir ödev olarak aşılanacaktır.» Bunun için ilkokulda bütün derslerin, eğitim sisteminin ve okul hayatının bu düsturda yazılı esasları tahakkuk ettirecek bir yolda ilerlemesi şarttır.

C) Fikri olduğu gibi bedeni gelişmişliğe de önem vermek ve hele irayı (karakter) ulusal derin tarihimizin gösterdiği yüksek derecelere çıkarmak büyük gayedir.

D) Eğitim ve öğretimde güdülen usul, bilgiyi, yurtdaşa maddi hayatta başarı elde ettiren bir cihaz haline getirmektir.

E) Eğitim her türlü urasadan (etki), yad ve yabancı fikirlerden uzak, üstün, ulusal ve yurtçu olmalıdır.

F) Talebenin girişim kapasitesini kırmadan, onun hayatta kusurlu olmaktan korumak için ciddi biryasav ve düzene, içten bir ahlak anlayışına alıştırmak,

G) Tarihini iyi bilmesi,

H) Türk dilinin ulusal, tükel (tam, bütün) bir dil haline gelmesi"40 kelimden fazla olan doğrudan alıntı yazımı bu şekilde olmalıdır.

İlkokul programının bu açık hedefleri dışında dönemin bir başka Maarif Vekili (Mili Eğitim Bakanı) Saffet Arıkan 1936 Maarif Vekaleti bütçesinin görüşülmesi sırasında sorulan sorulara verdiği cevaplarda şunları söylemektedir (TBMM, 1936, 5. Dönem) : "Arkadaşlar biz maarif işini evvela şu cepheden mütalea ediyoruz. Vatandaşa vereceğimiz bilgiyi maddi hayatında kendisine faydalı kılmak. Bizim esas prensibimiz budur. Bunun için takip ettiğimiz sıra da şudur: Evvela, bu noktai nazara, göre vatandaşa ne gibi malumat ve bilgi vereceğiz" diyerek ilkokulun hedeflerini açıç̧a vurgulamakta ve çalışmalarını bu hedef doğrultusunda planlamaktadır.

Müfettiş raporlarında yer alan tespitlerle de desteklenen dönemin eğitim anlayışında hayat için eğitim ilkesinin tercih edildiği, bu doğrultuda planlama ve çalışma yapıldığı görülmektedir. Oysa 2000-2010 dönemi ilköğretim programlarında da benzer amaçların yer aldığı görülse de uygulamada 2000-2010 döneminde, öğrencisini yaptığ testlerle, köy kasaba, şehir okulu ve yaşantısı fark edilmeden sınav odaklı bir yarışın içerisinde olduğu görülmektedir. Herkesin bu sınavlara gireceği, herkesin başarılı olması ve yaratılan "kaliteli okul" da okuma arzusu içinde olması gerektiği algısının oluşturulduğu, Devletin kaliteli ve kalitesiz eğitim veren iki farklı okulu bulunduğu düşüncesinin kabul edilir hale geldiği görülmektedir. Eğitimin piyasalaştırılarak alınır satılır hale gelmesi, dezavantajlı sınıfların eğitimden beklentilerinin azalmasına, sonucunda da sınıfsal çatışmaya temel oluşturacağı açıktır.

$\mathrm{Bu}$ yönüyle eğitim sisteminin kuruluş amaçlarından uzaklaştığı, temel yaşam bilgilerin verildiği ilkokul (ilköğretim okulu) anlayışından uzaklaşıldığı söylenebilir. Bugün temel eğitim olarak tanımlanan eğitim basamağında çocuğun kendisini, çevresini ve hayatı tanımasının yolunun açıldığı bu basmakta, iyi insan, iyi yurttaş ilkesinin ihmal edildiği söylenebilir.

Bu temelde, Oğuzkan (1980)'ın da belirttiği gibi eğitimin amacının her bir öğrencinin kapasitesinin en üst düzeyde ortaya çıkarılarak eğitilmesi olduğuna göre, açık yetersizliği olan öğrenciler dışında kalan diğer öğrenciler için de öğrencinin merkezde olduğu, bireysel kapasite ve farklılıkların sınıf içinde öğretmenler tarafından bilinmesi, öğretim çalışmalarına bu yönüyle önem verilmesi gerektiği sonucuna ulaşılabilir.

Sonuç olarak, sistemin eğitime bakış açısı aslında öğrenciden beklentisi ile eş değerdir. Eğitimin sınav odaklı bir sisteme doğru yönlendirildiği, 1739 sayılı Milli Eğitim Temel Kanunun 23 üncü maddesindeki ilköğretimin amaçları içerisinde yer alan çocukları hayata ve üst öğrenime hazırlama görevinin ağırlıklı olarak üst öğrenime hazırlama olarak uygulandığı, bu yönüyle temel eğitimin amacından uzaklaşıldığı, öğrencilerin 
de sınav ve dershane odaklı bir eğitim sürecine sürüklendiği söylenebilir.

1930-1940 döneminde sınıf seviyelerinin düşüklügüu, öğrencilerin bireysel yetersizliğinin giderilmesi için ek tedbirler alınması ve öğrencinin programa uygun olarak sınıf seviyesine ulaştırılması sorununun, 20002010 döneminde de var olan bu sorunun ek olarak sinavla öğrenci alan liselere girmek için düzenlenen sınavlara hazırlanma sorunu ile ağırlaştı̆̆ı anlaşılmaktadır. Bu tespitlere göre günümüz eğitiminde, öğrenci başarısının yapılan merkezi sınavlarda gösterilecek başarıya odaklandığı görülmektedir.

2000-2010 döneminde, öğrencisini yaptı̆̆ı etkinliklerle, üst eğitime ve hayata hazırlamaya çalışan öğretmelerin çoktan seçmeli testlerden arındırılmış bir çalışma yürütmeyi bırakması, herkesin bu sınavlara gireceği, herkesin başarılı olması ve yaratılan "kaliteli okul" da okuma arzusu içinde olması gerektiği algısının oluşturulması, devletin kaliteli ve kalitesiz eğitim veren iki farklı okulu bulunduğu düşüncesinin kabul edilir hale gelmesi, eğitim sistemi açısından olumsuz göstergeler olarak sayılabilir.

Başlangıçtan beri sınıf ortamlarında var olan özel eğitim ihtiyacı olan öğrencilere dönük sorunların giderilmesinde, 1930-1940 döneminde sadece akademik yetersizlik boyutunda ele alınan sorunun, 2000-2010 döneminde akademik ve sosyal sorun olarak ele alındığı, ancak dönemin olanaklarına rağmen eğitim ortamlarının yetersiz olduğu söylenebilir. 1930-1940 döneminde ilkokullarda öğrencilerin diş fırçalama, el yıkama, saç temizliği, bit pireden arındırılma gibi kişisel sağlıkları ile ilgili sorunların 2000-2010 döneminde teftiş raporlarında yer almasa da yer yer görüldüğ̈̈, 2000-2010 döneminde, taşımalı eğitime devam eden öğrencilerin temiz ve güvenilir ortamlarda yemek yeme sorununun ortaya çıtığı görülmektedir.

Taşımalı eğitim uygulaması ile köyde yaşayan küçük yaştaki çocukların iklim şartları dikkate alınmadan erken saatlerde araçlara bindirilerek uzun yolculuklar yapma zorunda bırakıldığı, köydeki sosyal yaşantı dengesinin bozulduğu, tarımsal üretimde yaşanan sorunların çözümü açısından köy yaşantısının ve tarımsal üretimin canlandırılması için taşımalı eğitime son verilerek öğretmenin tekrar köy hayatında yer almasının yararlı olacağı;

Öğrenci davranışları temasında ise günümüzde yetişecek kuşakta uyum sorunlarının var olduğunun vurgulandığı, bu sorunların İlköğretim Kurumlan Yönetmeliğinde yer alan okul içinde şiddet, taciz davranışlarının yaşamakta olduğumuz kadına şiddet ve tecavüz olaylarının TBMM'de kabul edilen içeriği tartışılmaya devam eden kanunun aksine yıllar önce ilköğretim okullarına girdiği, bu yönüyle kadına şiddet ve tecavüz olaylarının temelinin çok küçük yaşlarda yaşandığı, tehlikenin yetişkinleri cezalandırma boyutunu çoktan geçtiği dikkate alınmalıdır.

En basit tanımıyla, önceden planlanmış eğitsel amaçları (bilgi, beceri ve tutumu) planlı bir süreç içinde öğrencilere kazandıran örgüt (Başaran, 2006) olarak kabul edilen okulların, hele de ilköğretim okulları gibi 714 yaş arası çocukların eğitim gördüğü ilköğretim okullarının, nadir rastlanılacak suç türlerini de disiplin yönetmeliklerine taşımaları, gelecek için endişe verici bir tespittir. Önlemlerin ve eğitim politikalarının bu tehlikeyi kapsayacak şekilde düzenlenmesinin, ilköğretimin amaçlarının önce hayata, sonra üst öğrenime hazırlama olarak uygulanması gerektiği söylenebilir.

\section{Yazarın Beyanı}

\section{Araştırmacıların katkı oranı beyanı: \%100}

Çatışma beyanı: Tek yazarlı olduğu için çıkar çatışması yoktur.

Destek ve teşekkür: Tez danışmanım Prof. Dr. İnayet AYDIN'a çalışmada yaptığı destekten dolayı teşekkür ederim.

\section{Kaynaklar}

Akyüz, Y. (2013). Türk eğitim tarihi M.Ö 1000 - M. S. 2013. Ankara: Pegem Akademi Yayınları

Altunya, N. (2009). Milli eğitimde Mustafa Necati dönemi. İstanbul: Başarı Yayımcılık

Başaran, İ.E. (2006). Türk eğitim sistemi ve okul yönetimi. Ankara: Ekinoks 
Başgöz, İ. (1995). Türkiye'nin eğitim çıkmazı ve Atatürk. Ankara: Kültür Bakanlığı Yayınları/1754

Binbaşıŏ̆lu, C. (2005). Türk Eğitim Dü̧̈üncesi Tarihi. Ankara: Anı Yayıncılık.

Christensen, L.B., Johnson, R.B., \& Turner, L.A. (2015). Araştırma yöntemleri desen ve analiz. (Ahmet Aypay, Çev. Ed.). Ankara: Anı Yayıncılık.

Denzin, N.K., \& Lincoln, Y.S. (2005). The sage handbook of qualitative research. Thousand Oak.: Sage.

Edis, A. B. (1947). Milli eğitim düsturu (programlar) ilköğretim bölümü. İstanbul: Güven Basımevi

Erçıktı, U. G. (2009). İlköğretim okulları 4.ve 5. sinıf öğretmenlerinin karşılaştıkları disiplin sorunları. (Yayınlanmamış Yüksek Llisans Tezi). Beykent Üniversitesi, İstanbul.

Ergün, M. (1997). Atatürk devri Türk Ĕ̆itimi. Ankara: Ocak Yayınları

Feyzoğlu, O. G. (1982). Atatürk ilkeleri ve inkılabımız. İstanbul: MEB Hükümet programları.

Hükümet Programları. (2012). 15 Ekim 2013 tarihinde https://www.tbmm.gov.tr/develop/owa/tutanak_dergisi_pdfler.meclis_donemleri?v_meclisdonem=0 adresinden erişilmiştir.

İnan, R. (1980). Mustafa Necati kişiliği, ulusal eğitime bakışı, konuşma ve anıları. Ankara: Türkiye İş Bankası Kültür Yayınları.

Kodamanoğlu, M., N. (1964). Türkiye'de eğitim (1923-1960). Ankara: MEB

Küçükahmet, L. (1999). Öğretimde planlama ve değerlendirme. İstanbul: Alkım Yayınları

MEB. (2015, 10 Nisan). Resmi istatistikler. 15 Ekim 2013 tarihinde https://sgb.meb.gov.tr/www/resmiistatistikler/icerik/64, Türkiye İstatistik Kurumu Eğitim İstatistikleri bağlantısı (haber bültenleri, veriler, yayınlar ve metaveri). Milli eğitim istatistikleri. www.tuik.gov.tr/PreTablo.do7alt id=1018 adresinden erişildi.

Okullarda bit salgını başladı. (2013, 29 Mart). 25 Aralık 2013 tarihinde http://www.erganihaber.net/haber-918Okullarda-bit-salgini-basladi.html adresinden erişilmiştir.

Özel, E. (2007). Atatürk dönemi Türk eğitim politikaları. (Yayınlanmamış Yüksek Lisans Tezi). Dumlupınar Üniversitesi, Kütahya.

Öztürk, K. (1968). Türkiye Cumhuriyeti hükümetleri ve programları. İstanbul: Ak Yayınları.

Para ödendi, anne serbest ama artık evlat yok. (2010, 5 Ocak). 25 Aralık 2013 tarihinde http://www.ntv.com.tr/id/25078162/- adresinden erişilmiştir.

Robson, C. (2015). Bilimsel araştırma yöntemleri gerçek dünya araştırması. (Ş. Çınkır \& N. Demirkasımoğlu, Çev. Ed.). Ankara: Anı Yayıncilık.

Taymaz, H. (2005). Eğitim sisteminde teftiş, kavramlar, ilkeler, yöntemler. Ankara: Pegam A Yayıncllı.

Urfa'da Okullarda Bit Salgını Haberine Açılama. (2013, 29 Mart). 25 Aralık 2013 tarihinde http://sanliurfagazetesi.com/haber112721-Urfada-Okullarda-Bit-Salgini.html adresinden erişilmiştir.

Yıldırım, A. \& Şimşek, H. (2005). Sosyal bilimlerde nitel araştırma yöntemleri. Ankara: Seçkin Yayıncılık. 


\section{EXTENDED ABSTRACT}

\section{Introduction}

The aim of this present survey is to search for answers to the basic approaches, basic similarities and differences related to the "student perception" of the periods from 1930 to 1940 and from 2000 to 2010 by examining the inspection papers found in the archives of the centre, district, town and village primary schools of Afyonkarahisar Province.

\section{Method}

This study is in the documentary screening model. Screening models are research models that attempt to present a situation that exists now or in the past as it is. In this model, data is collected in order to provide facts about past events, to establish relationships between facts and events, and to reach conclusions. These data are historical data sources. Written and printed documents may be sources of historical data, as well as remains from the relevant period (Karasar, 1999). Document review technique is used. Document review covers the analysis of written materials that contain information about facts or events that are intended to be investigated. The change in the relevant legal texts that indicate the way the periods look at the students has been put forward as it has been historically.

\section{Results}

It is compared between 1930 and 1940, which coincided with the period of the rise of the Republican ideology, and between 2000 and 2010, which coincided with the last period of the Republic. By analysing the ideology of the Republic and the evolution of this ideology, the philosophy of education that dominated both periods, the political and ideological perspectives that influenced education, the social structure and dynamics were tried to be determined. In this dimension, whether there are similarities and differences in the way the system looks at the student was examined, identified similarities and differences, individual differences, student health and student behaviour/disciplinary affairs were examined in three categories.

In the category of individual differences, it is seen that legal regulations exist in both periods, the problem of low class levels in the period 1930-1940, taking additional measures to eliminate the individual inadequacy of students and bringing the student to the class level in accordance with the program continues in the period 2000-2010, aggravated by the problem of preparing for central exams.

In the category of the students' health, it is understood that the content of the definitions and recommendations made in the period 1930-1940 consists of the sanitary care of the students, cleaning habits, cleaning and maintenance of the body, including teeth, hair, clothing, the arrival of teachers in small settlements such as towns and villages is also important from the point of view of community health, the teacher had to have roles other than the role of a teacher. For the period from 2000-2010, it is understood that together with the problems caused by the cleaning of the food, dining hall and the personnel responsible for this work, louse cases are seen in schools in present-day Turkey, as well as the problems of the students transported by the transportable education system.

According to the findings obtained regarding student behaviour and discipline category, the Primary Schools Instruction in the period 1930-1940 and the Primary Schools Directive in the period 2000-2010 are similar to each other, but the inclusion of acts such as violence, threats, political action, alcohol use, harassment in the definition of behaviour that will require punishment for changing schools in the period 2000-2010 indicate the danger faced by schools and society in this period.

\section{Conclusion}

According to these definitions, it is seen that in the current education, student success is focused on the success that will be shown in the central exams, so the idea that there are two different schools that provide quality and poor quality education has become accepted. Education is directed towards an exam-oriented system, in this aspect it is away from the purpose of basic education; in addressing the problems facing students with special educational needs, in the period 2000-2010, despite the opportunities of the period, the 
educational environment is insufficient; in terms of the students' health, in the period 1930-1940 in primary schools, the problems of students like brushing teeth, washing hands, cleaning hair, cleaning louse and fleas were caused by the practice of carrying education in the period 2000-2010, when young children living in the village were put on vehicles in the early hours without taking into account the climate conditions and forced to make long trips, the balance of social life in the village is broken, so it would be useful for the teacher to return to the village by ending the transport education to revive the village life and agricultural production in terms of solving the problems experienced in agricultural production; it is understood that the crimes that are the subject of judicial investigation in the country, the crimes of violence and harassment of women, which are concentrated, go to primary schools, and the danger has already passed the dimension of punishing adults. It can be said that measures and education policies should be regulated to cover this danger. 